\title{
Hasil PISA Indonesia Tahun 2018 Turun Dibanding Tahun 2015
}

\author{
Mohammad Tohir \\ Universitas Ibrahimy, Situbondo, Indonesia \\ matematohir@ibrahimy.ac.id
}

Jakarta, Kemendikbud --- Hasil studi Programme for International Student Assessment (PISA) 2018 telah dirilis pada hari Selasa, 3 Desember 2019. Berdasarkan hasil studi tersebut Peringkat PISA Indinesia Tahun 2018 Turun apabila dibandingkan dengan Hasil PISA tahun 2015. Studi pada tahun 2018 ini menilai 600.000 anak berusia 15 tahun dari 79 negara setiap tiga tahun sekali. Studi ini membandingkan kemampuan matematika, membaca, dan kinerja sains dari tiap anak.

Adapun untuk kategori kemampuan membaca, Indonesia berada pada peringkat 6 dari bawah alias peringkat 74 . Skor rata-rata Indonesia adalah 371, berada di bawah Panama yang memiliki skor rata-rata 377. Sedangkan peringkat pertama diduduki oleh China dengan skor rata-rata 555. Posisi kedua ditempati oleh Singapura dengan skor rata-rata 549 dan Makau, China peringkat tiga dengan skor rata-rata 525. Sementara Finlandia yang kerap dijadikan percontohan sistem pendidikan, berada di peringkat 7 dengan skor rata-rata 520 .

Lantas, untuk kategori matematika, Indonesia berada di peringkat 7 dari bawah (73) dengan skor rata-rata 379. Indonesia berada di atas Arab Saudi yang memiliki skor rata-rata 373. Kemudian untuk peringkat satu, masih diduduki China dengan skor rata-rata 591. Lalu untuk kategori kinerja sains, Indonesia berada di peringkat 9 dari bawah (71), yakni dengan rata-rata skor 396. Berada di atas Arab Saudi yang memiliki rata-rata skor 386. Peringkat satu diduduki China dengan rata-rata skor 590.

Berdasarkan laporan terbaru tersebut, performa Indonesia terlihat menurun jika dibandingkan dengan laporan PISA 2015. Hal ini bisa dilihat dari tiga aspek yang dinilai. Berikut perbandingannya:

PISA 2015

- kemampuan membaca: 397

- kemampuan matematika: 386

- kemampuan kinerja sains: 403
PISA 2018

- kemampuan membaca: 371

- kemampuan matematika: 379

- kemampuan kinerja sains: 396

Untuk diketahui, indikator dan metode yang digunakan untuk survei PISA 2015 dan 2018 sama. Hal yang membedakan, jika tahun 2015 ada 70 negara yang disurvei, maka tahun 2018 bertambah menjadi 79 negara.

Dengan demikian, Kementerian Pendidikan dan Kebudayaan (Kemendikbud Menanggapi hasil survie tersebut, Menteri Pendidikan dan Kebudayaan (Mendikbud) Nadiem Anwar Makarim menyampaikan bahwa penilaian yang dilakukan PISA merupakan masukan berharga untuk mengevaluasi dan membenahi sistem pendidikan di Indonesia.

"Hasil penilaian PISA menjadi masukan yang berharga untuk mengevaluasi dan meningkatkan kualitas pendidikan di Indonesia yang akan menjadi fokus Pemerintah selama lima tahun ke depan. Menekankan pentingnya kompetensi guna meningkatkan kualitas untuk menghadapi tantangan abad 21," disampaikan Mendikbud Nadiem Anwar Makarim dalam acara rilis hasil PISA 2018, di kantor Kemendikbud, Jakarta pada Selasa (3/12). 
Guna mencapai tujuan tersebut, Kemendikbud akan melakukan inovasi dan terobosan yang diperlukan untuk mempercepat proses dan melakukan lompatan di bidang pendidikan.

Salah satu yang sedang dikaji Kemendikbud adalah pembenahan sistem asesmen. Menurut Mendikbud, asesmen perlu dibuat agar fokus pada kompetensi mendasar yang berguna secara luas. Hasil asesmen juga akan dilaporkan dalam bentuk yang bermanfaat bagi perbaikan praktik pengajaran di kelas maupun perumusan kebijakan pendidikan.

"Kita harus berani berubah dan berbenah. Sesuai dengan arahan Presiden untuk menciptakan SDM unggul, kami akan terus menelaah upaya untuk melakukan terobosan-terobosan," tutur Mendikbud.

"Peningkatan kualitas pembelajaran menjadi hal yang utama. Kami akan terus melibatkan guru dan orang tua. Penting bagi Pemerintah untuk memberikan ruang bergerak yang cukup untuk pihak-pihak terkait dapat terlibat dan ikut belajar," imbuh Mendikbud Nadiem.

Dalam satu dekade terakhir, fokus Pemerintah adalah untuk meningkatkan akses terhadap pendidikan dan telah membuahkan hasil. Hal ini terlihat dari peningkatan persentase penduduk yang bersekolah. Pada tahun 2000, hanya 39 persen penduduk usia 15 tahun yang bersekolah pada jenjang SMP atau SMA, sementara pada tahun 2018, angka tersebut meningkat menjadi 85 persen.

Dari Paris, Andreas Schleicher, Direktur Pendidikan dan Keterampilan OECD, mengatakan setelah kemajuan luar biasa dalam akses ke sekolah, sekarang saatnya bagi Indonesia untuk memastikan pengajaran dan pembelajaran yang berkualitas.

"Semua siswa dapat mencapai tinggi jika dukungan yang baik dan tepat sasaran diberikan. Terutama bagi siswa yang kurang beruntung. PISA menunjukkan bahwa kemiskinan bukanlah takdir," tulis Andreas kepada Kepala Badan Penelitian dan Pengembangan (Balitbang) Totok Suprayitno.

\section{Pustaka}

Tohir, Mohammad. 2019. Hasil PISA Indonesia Tahun 2018 Turun Dibanding Tahun 2015. Tersedia Online: https://matematohir.wordpress.com/2019/12/03/hasil-pisa-indonesiatahun-2018-turun-dibanding-tahun-2015/ [03 Desember 2019] 